\title{
Enantioselective Palladium-Catalyzed Carbozincation of Cyclopropenes
}

\author{
Katja Krämer, Paul Leong, and Mark Lautens* \\ Department of Chemistry, University of Toronto, 80 St. George Street, Toronto, \\ Ontario M5S 3H6, Canada \\ mlautens@chem.utoronto.ca
}

Supporting Information

Table of Contents

Spectral Data for Cyclopropenes 1, 2a-d, 13 and 18

S2

Spectral Data for Cyclopropanes 5a-i, 6a-6d, 9 and 10

S9 


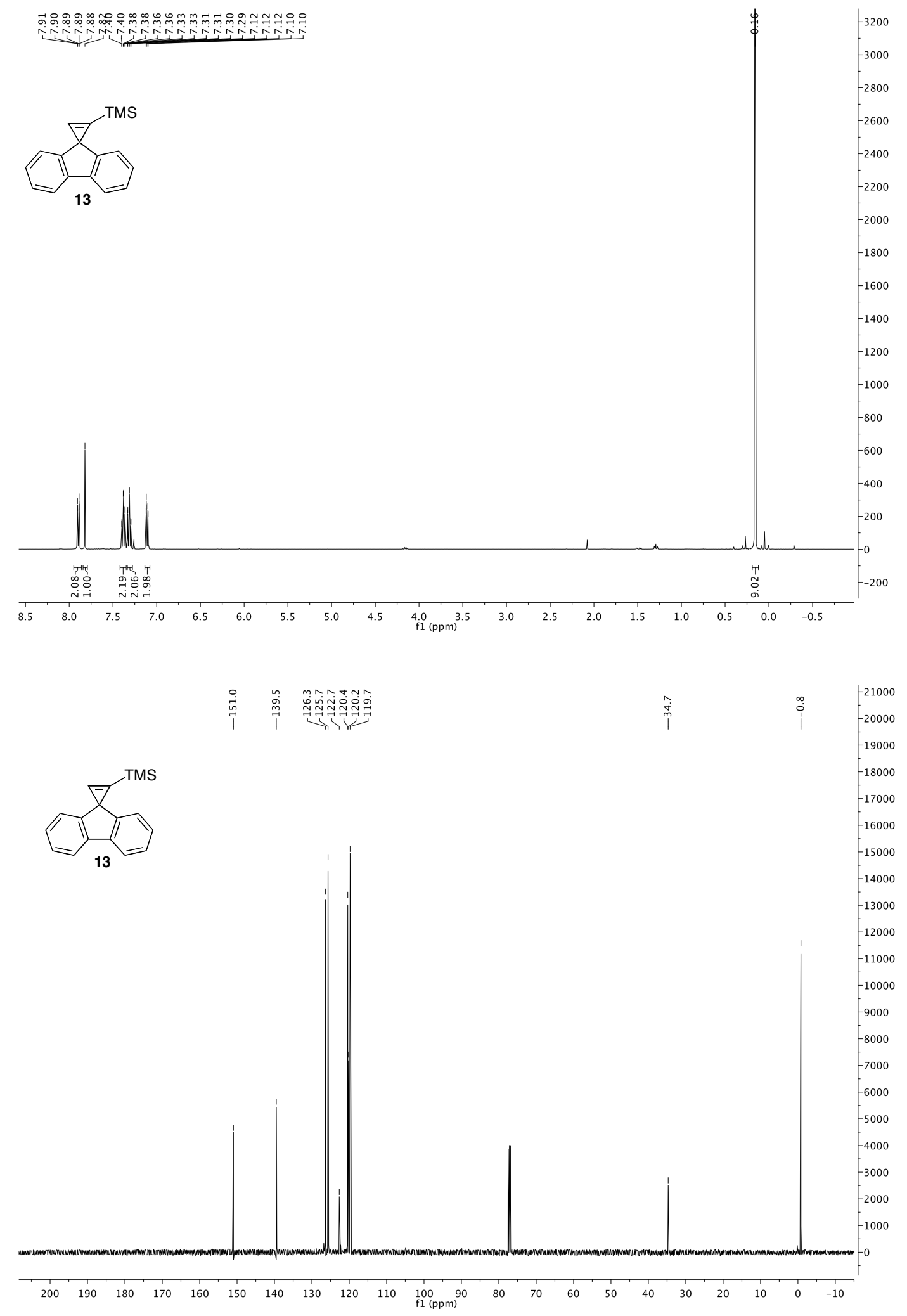




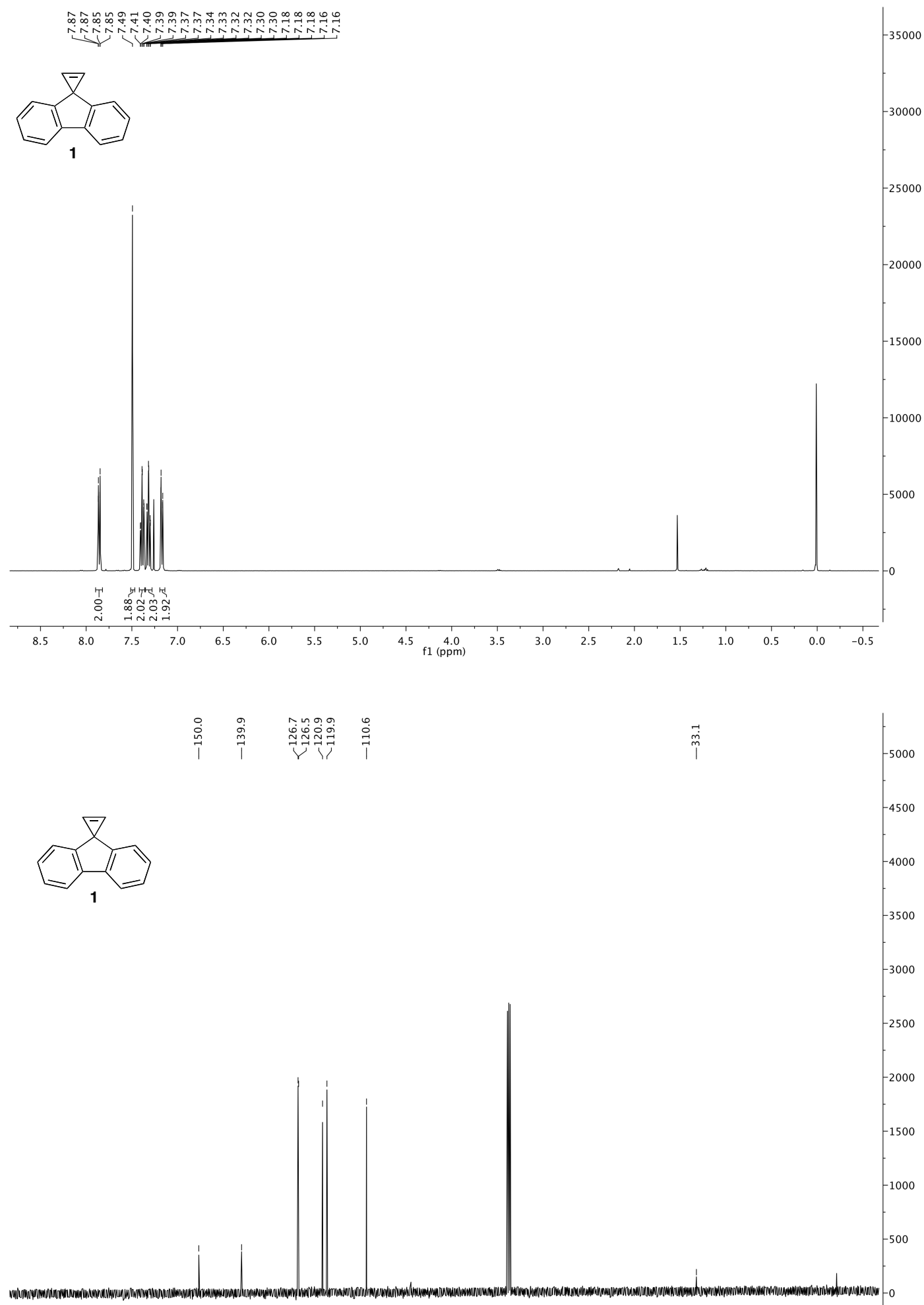

(1)

$\begin{array}{llllllllllllllllll}180 & 170 & 160 & 150 & 140 & 130 & 120 & 110 & 100_{\mathrm{f} 1(\mathrm{pmm})} & 80 & 70 & 60 & 50 & 40 & 30 & 20 & 10 & 0\end{array}$ 


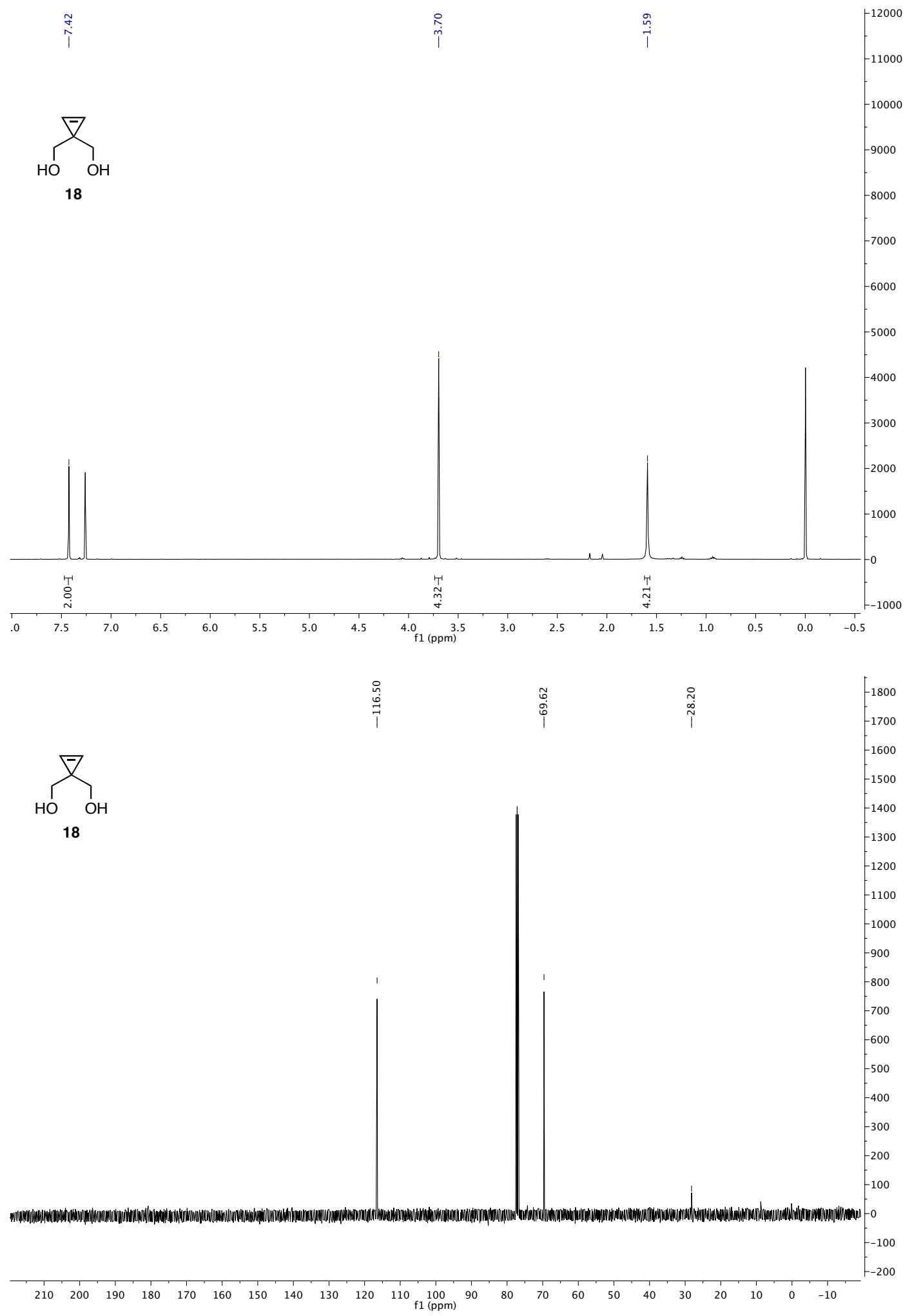




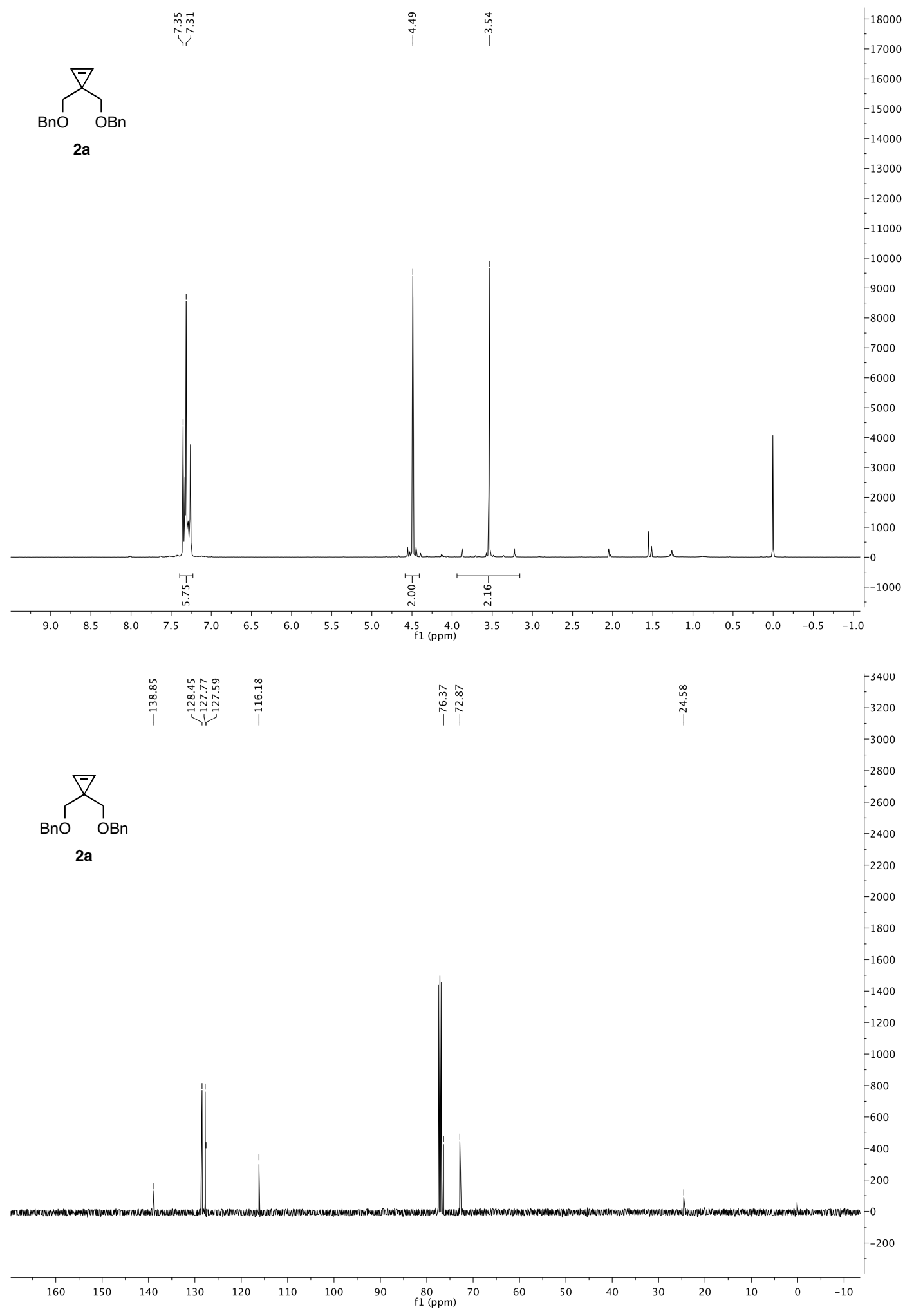




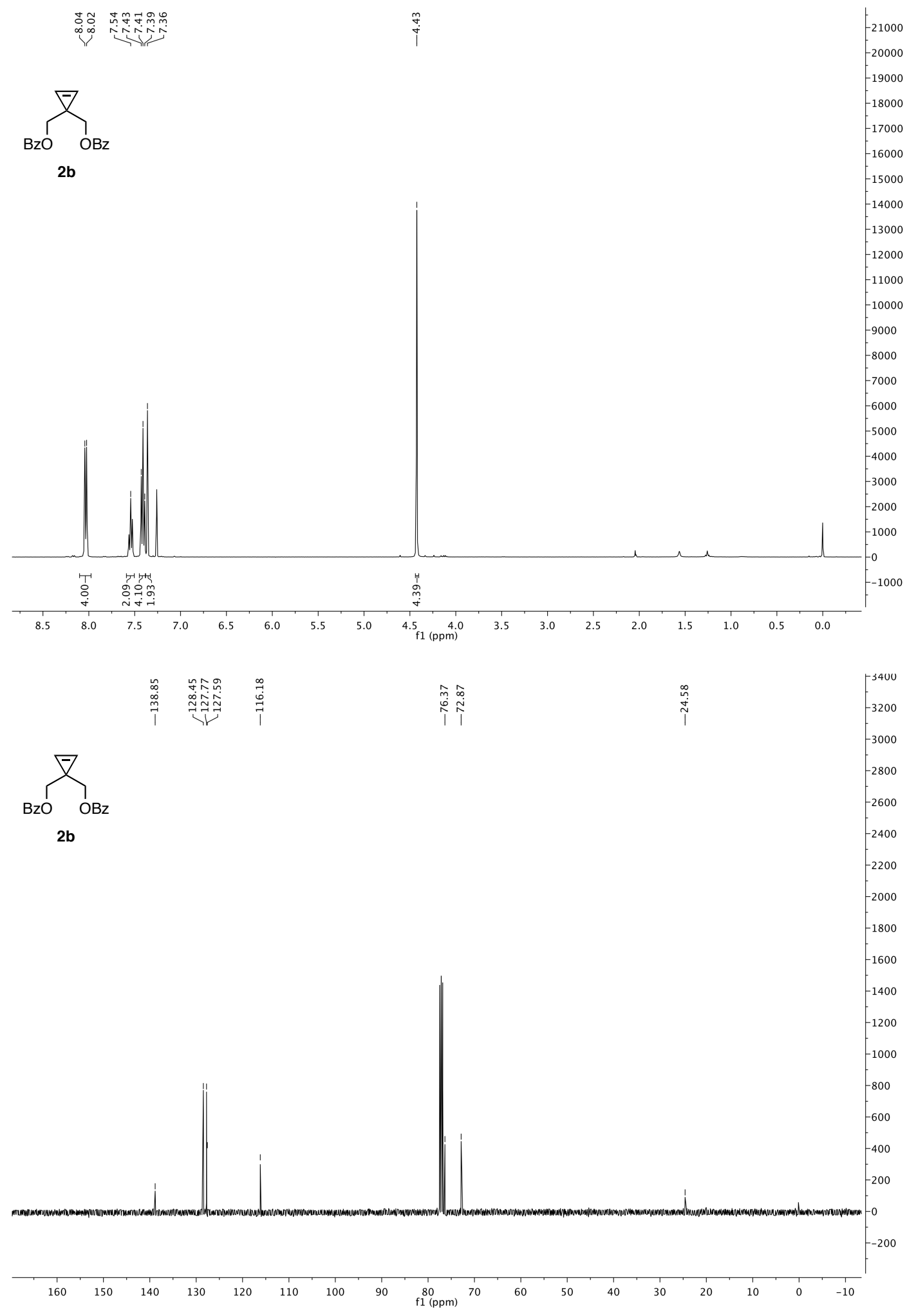




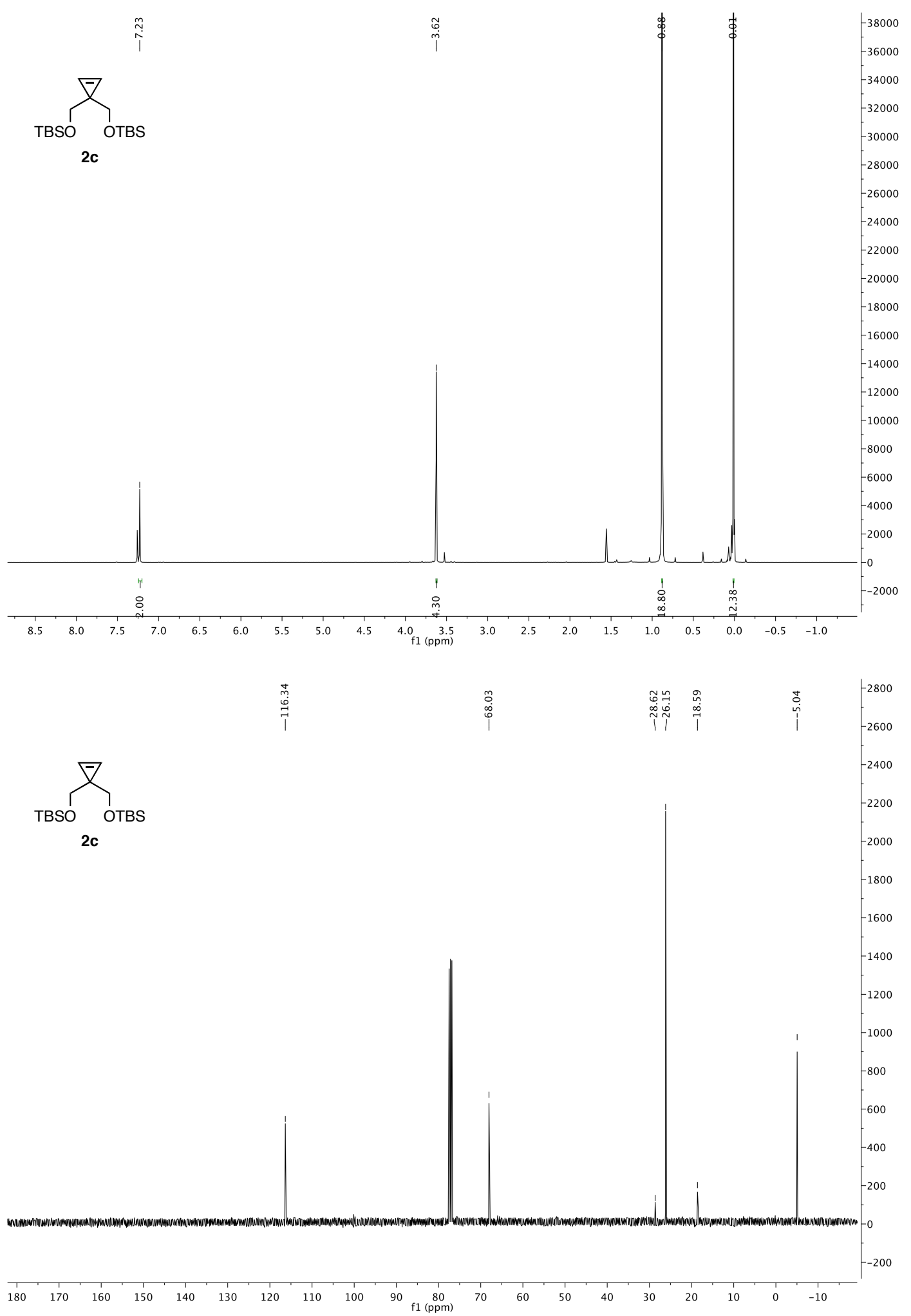




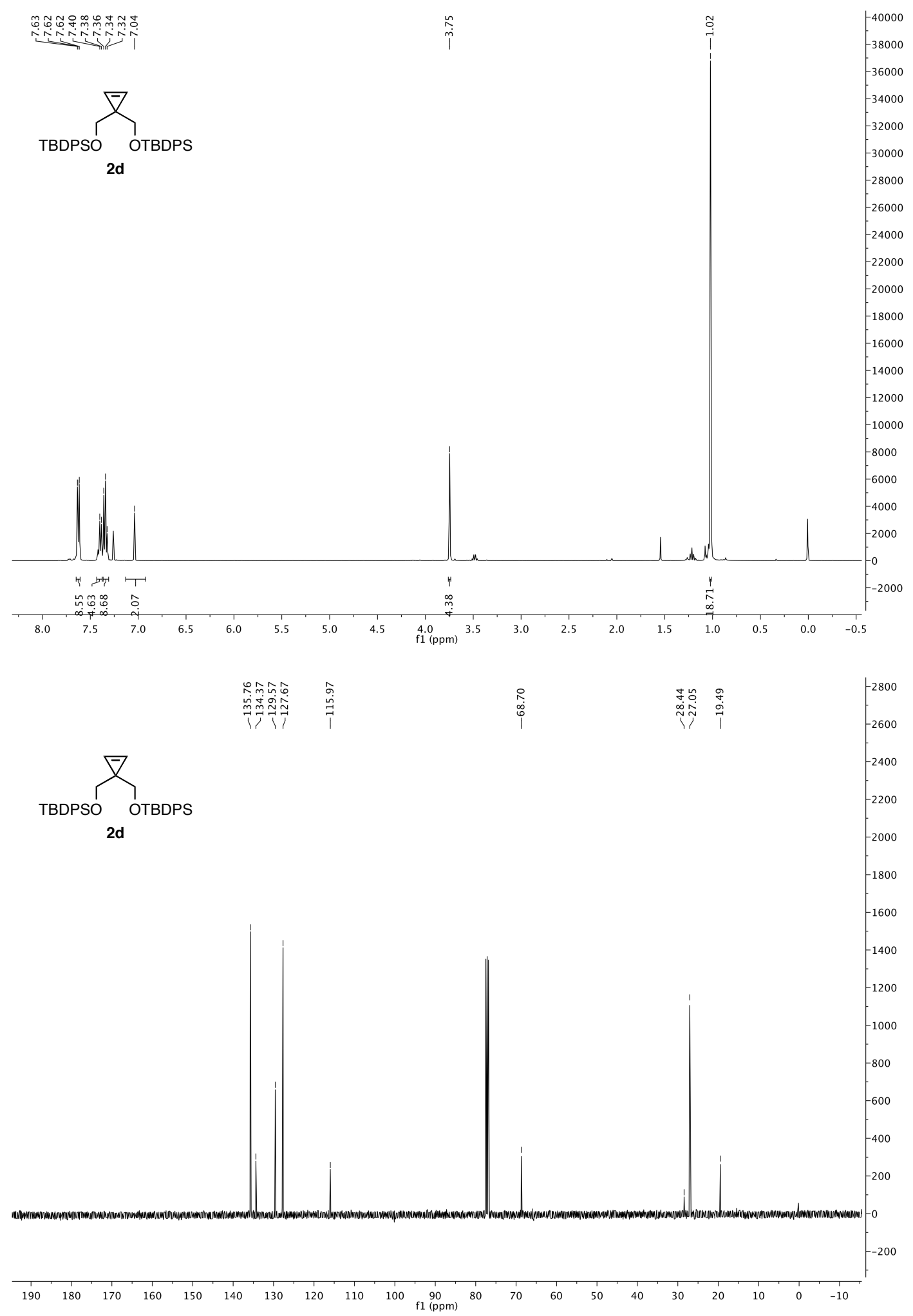



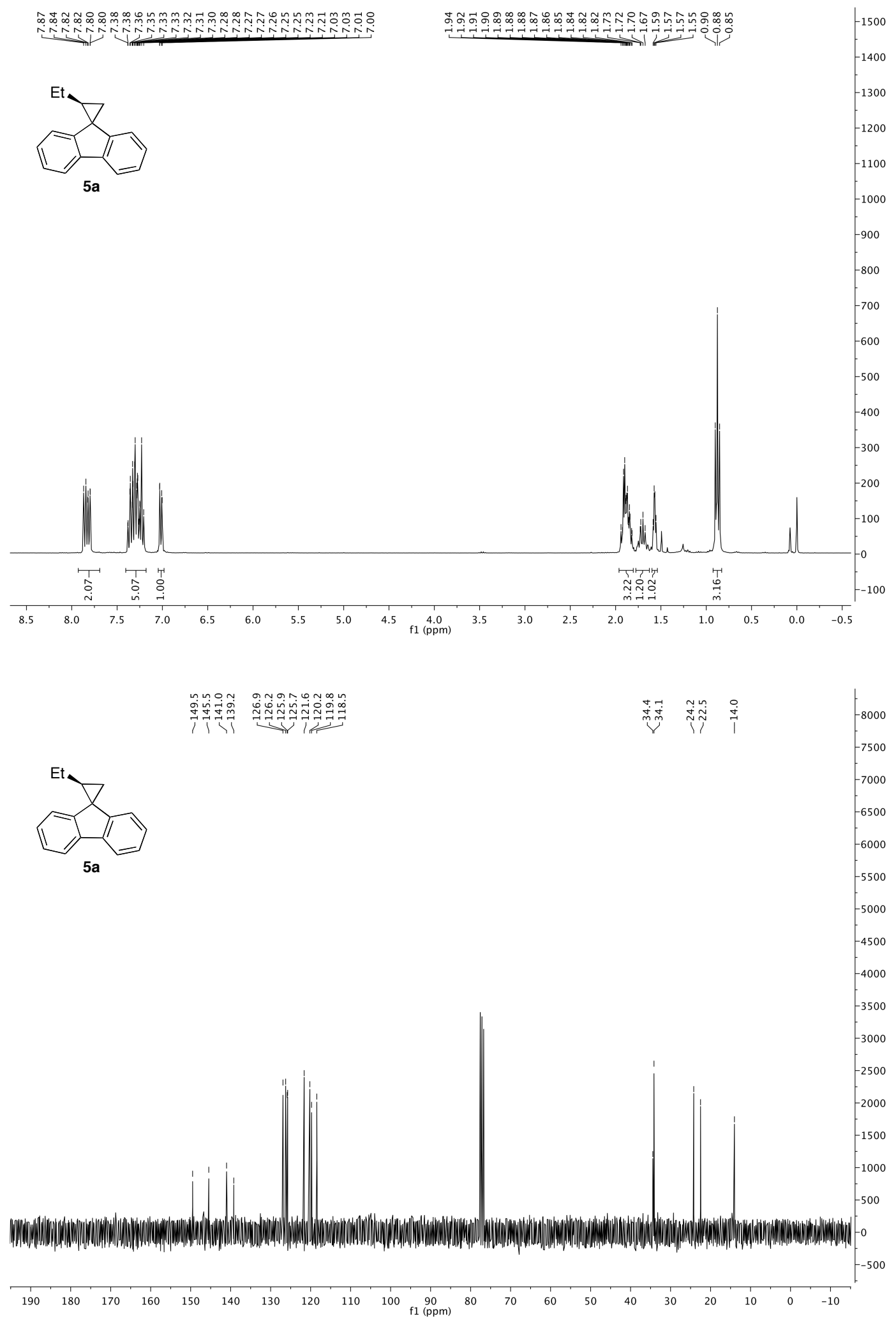

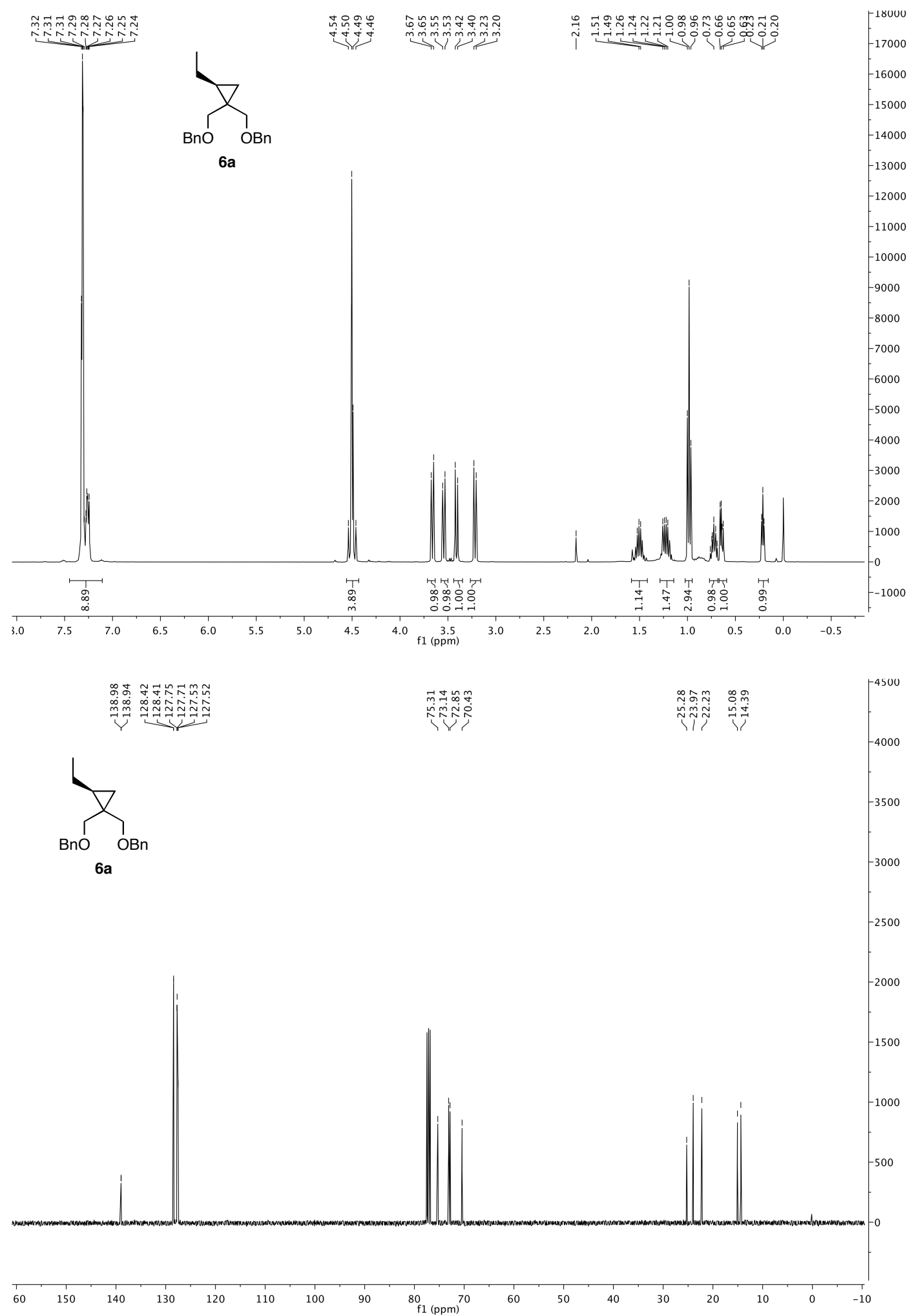


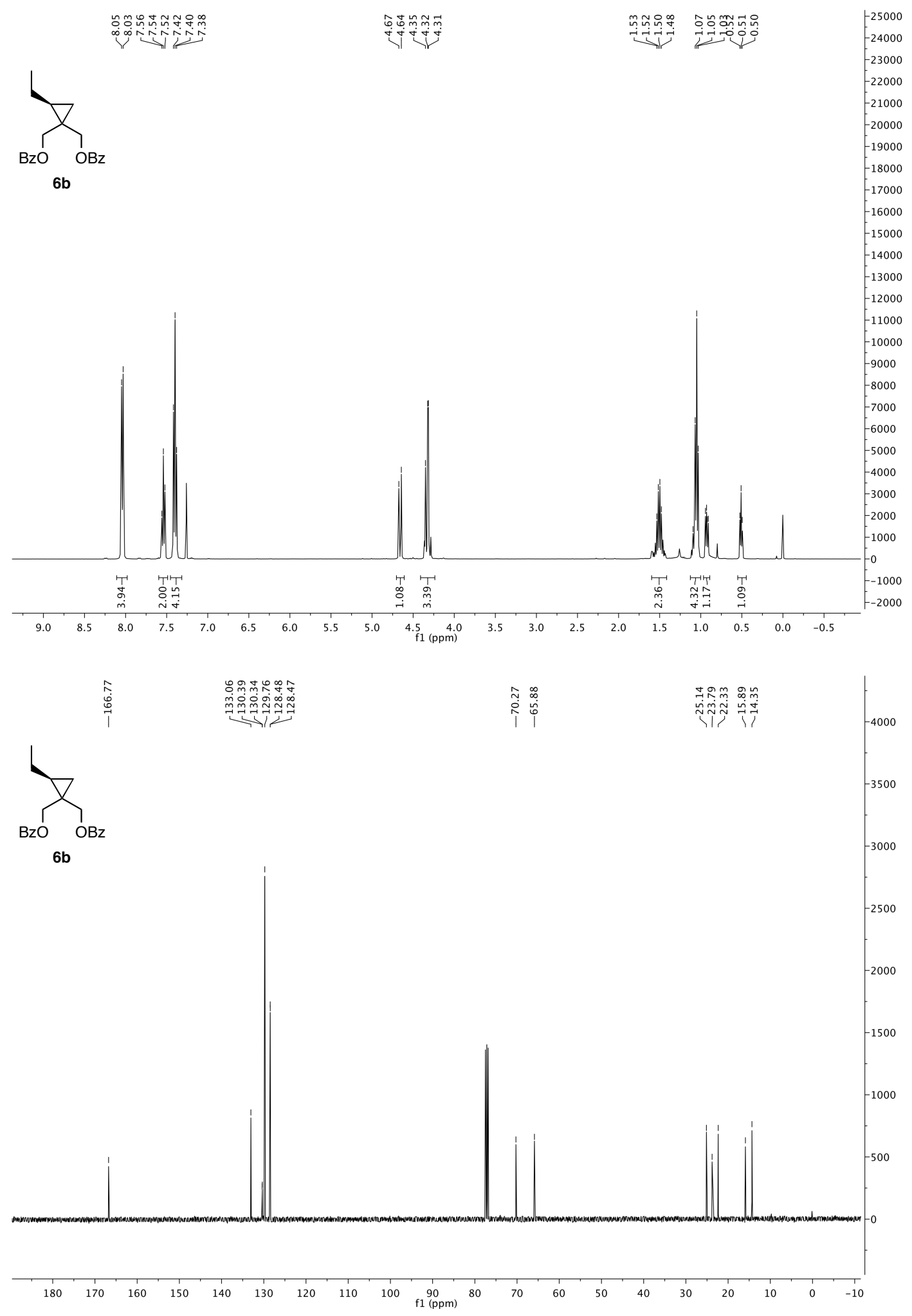




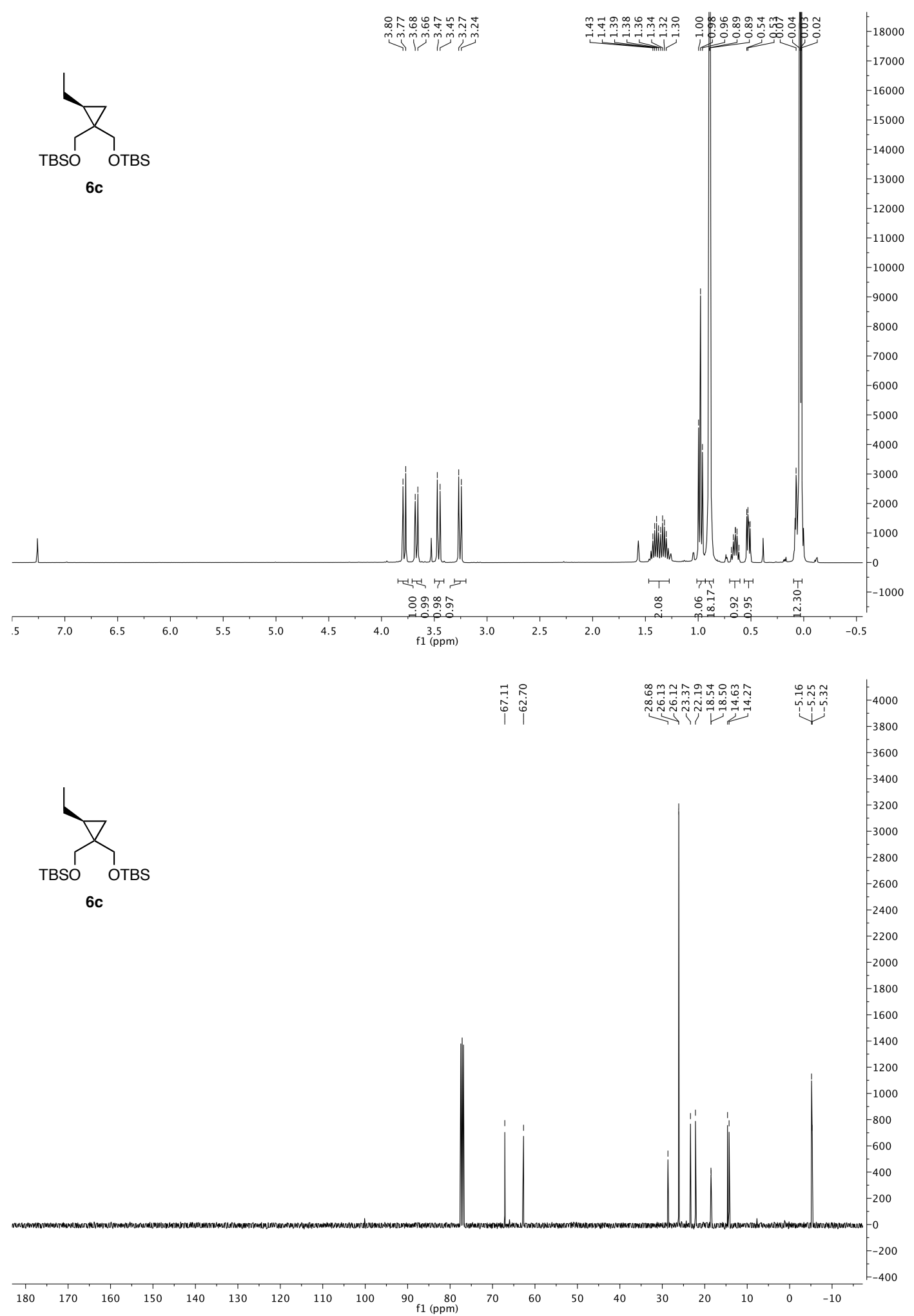



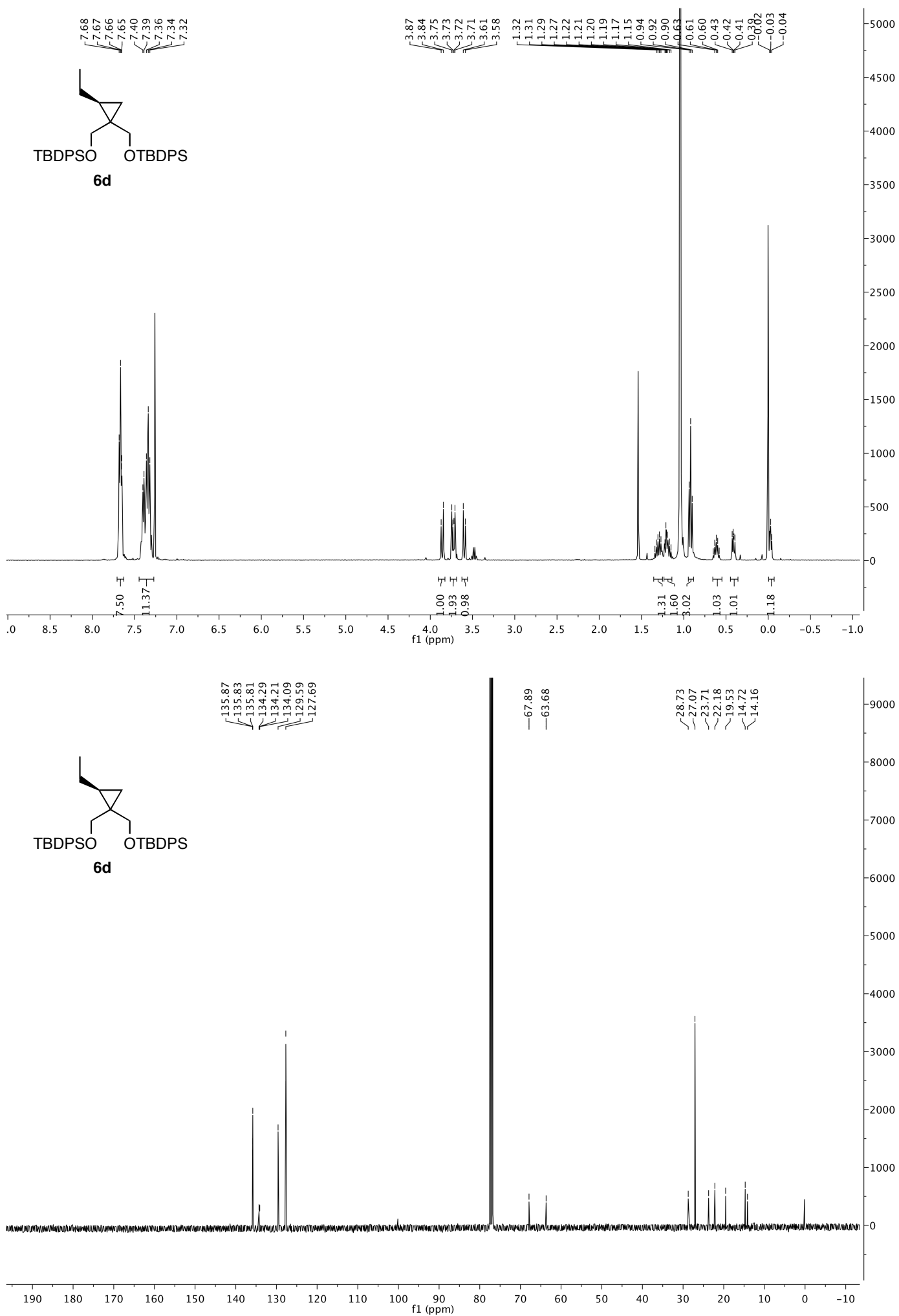


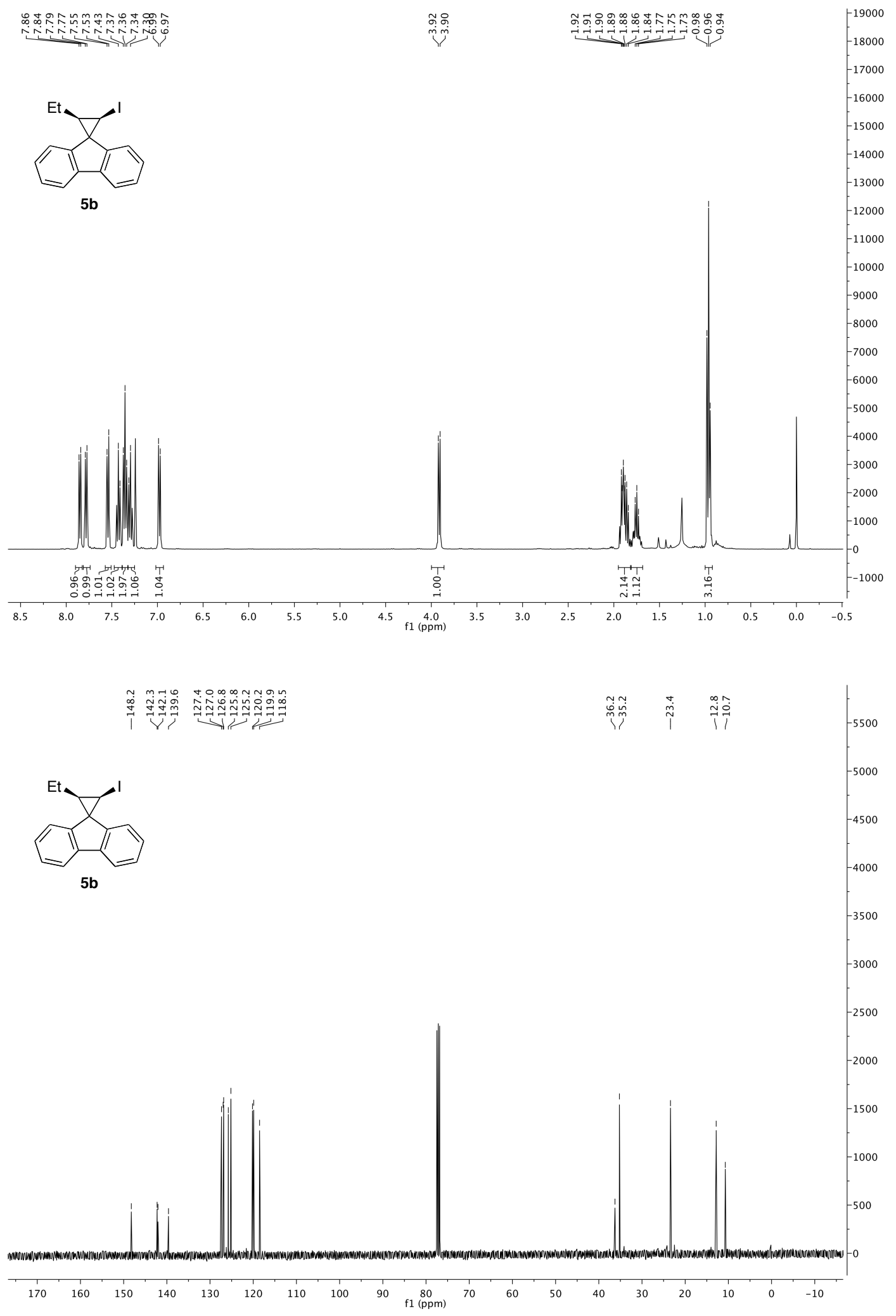




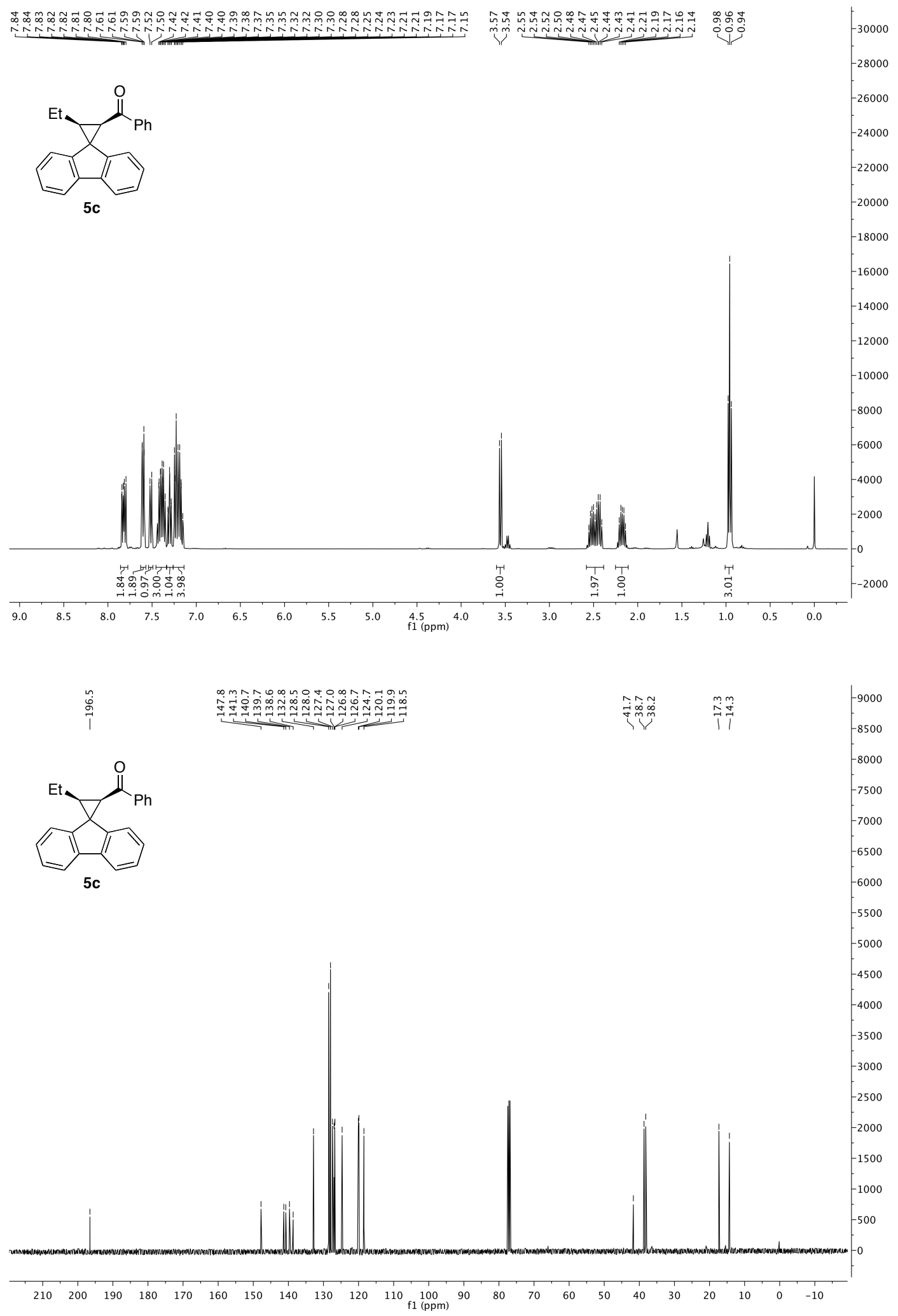



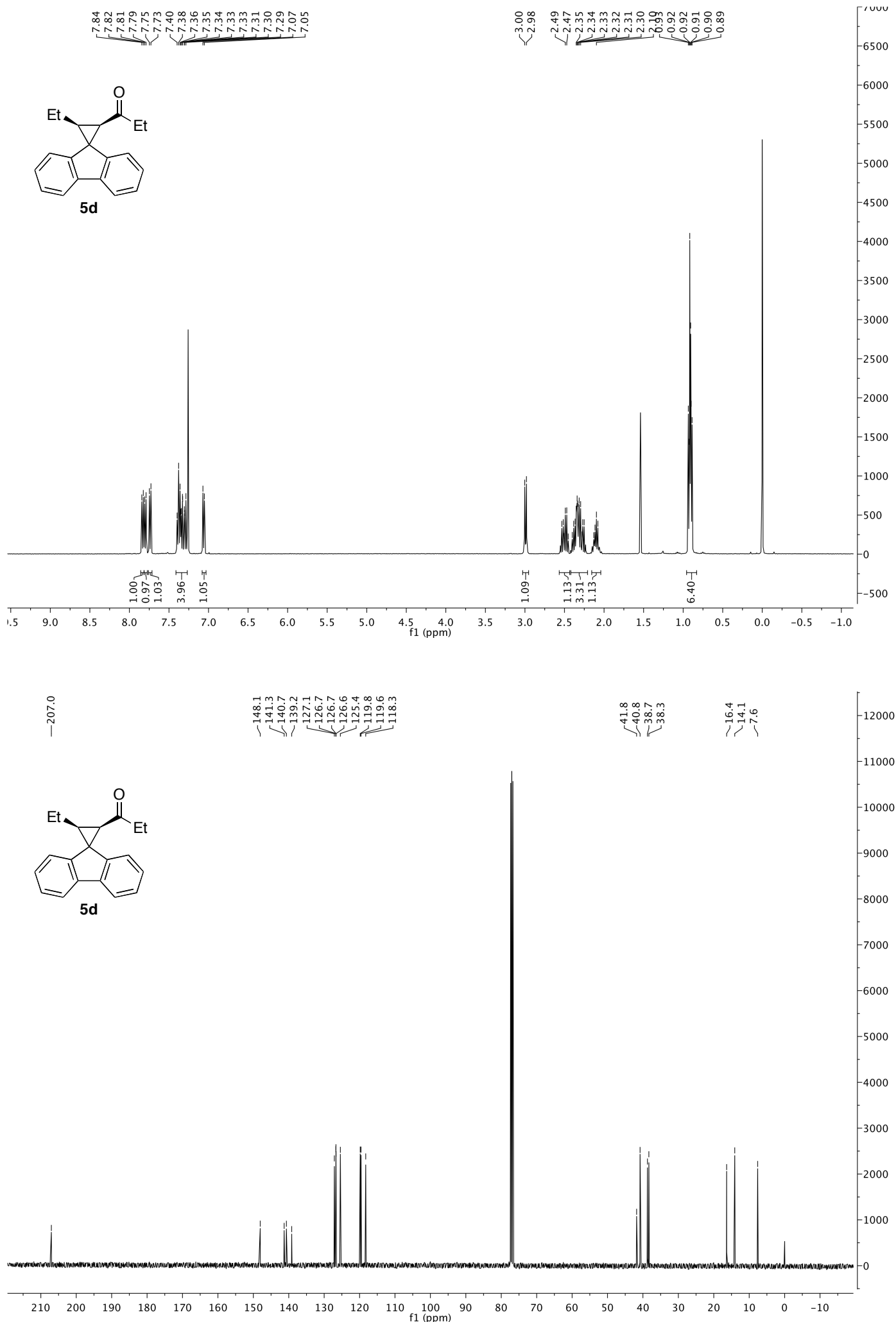

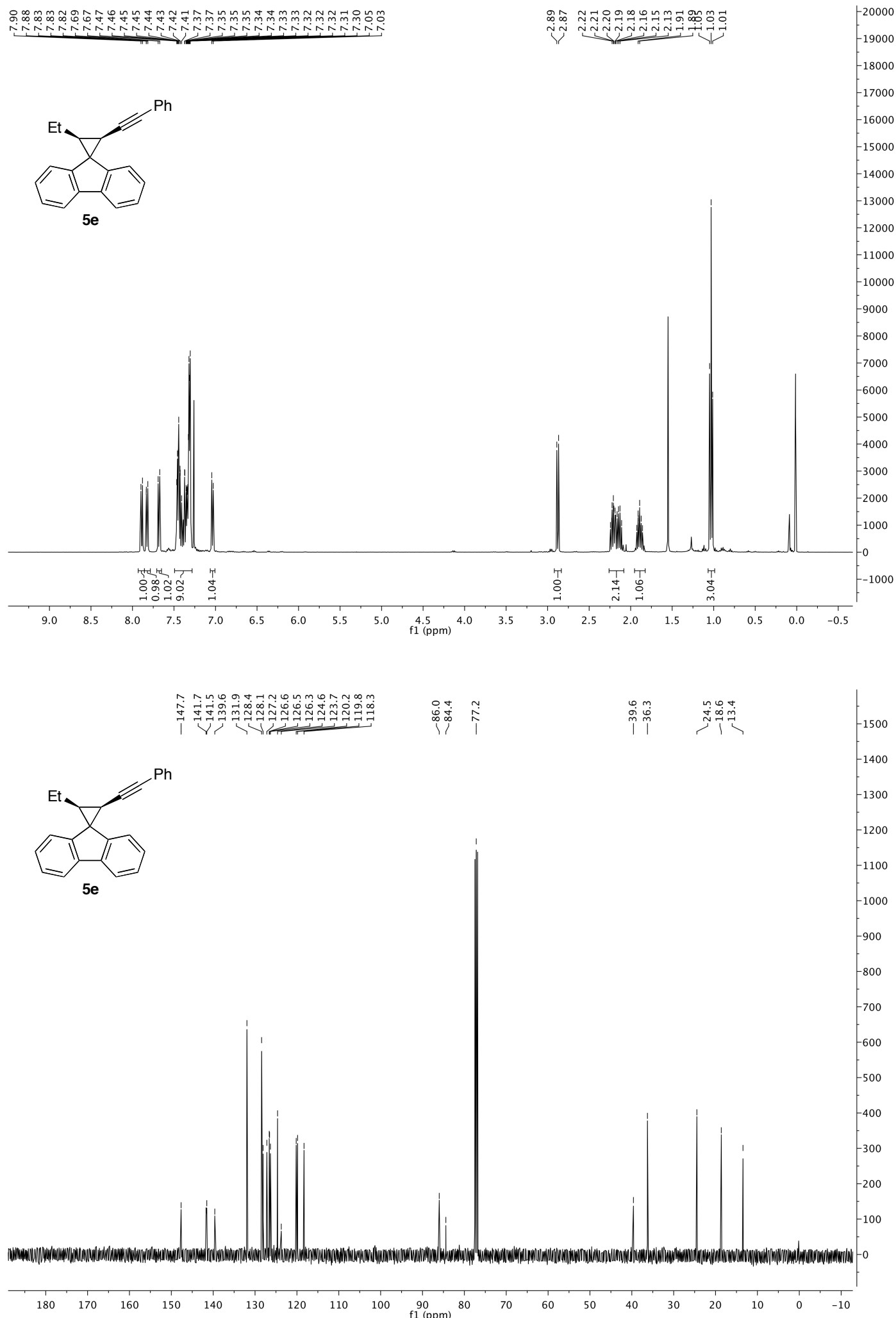

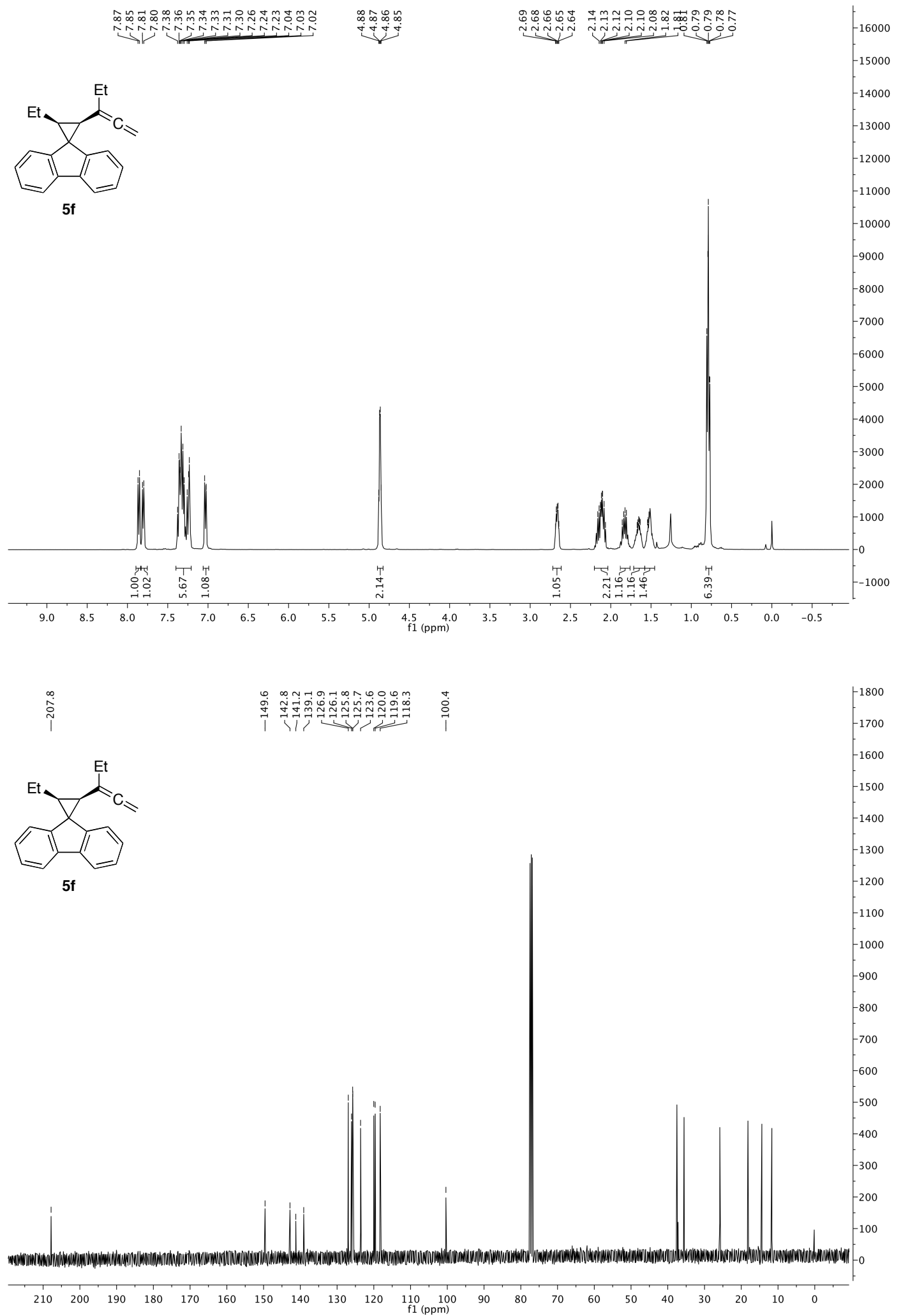

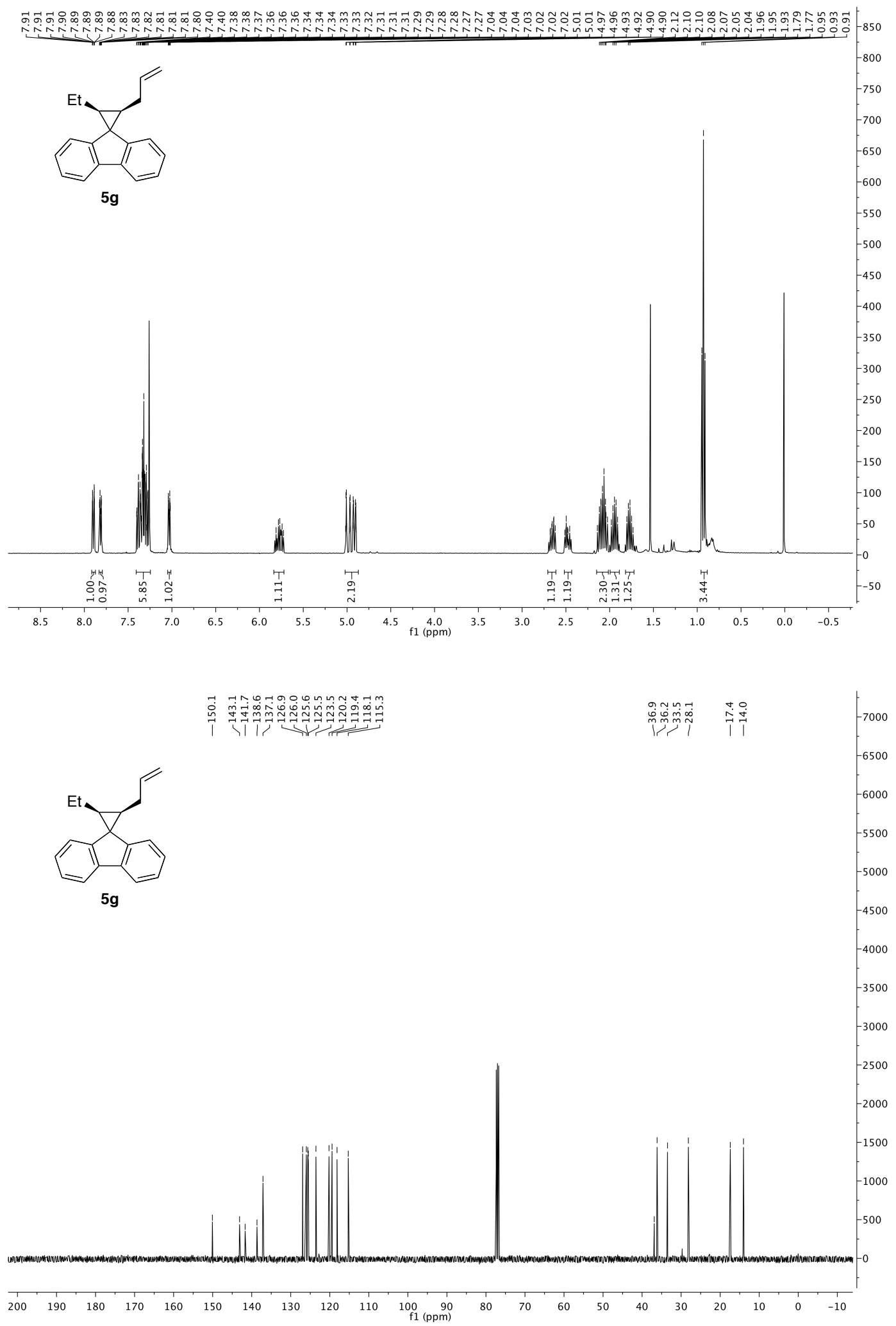

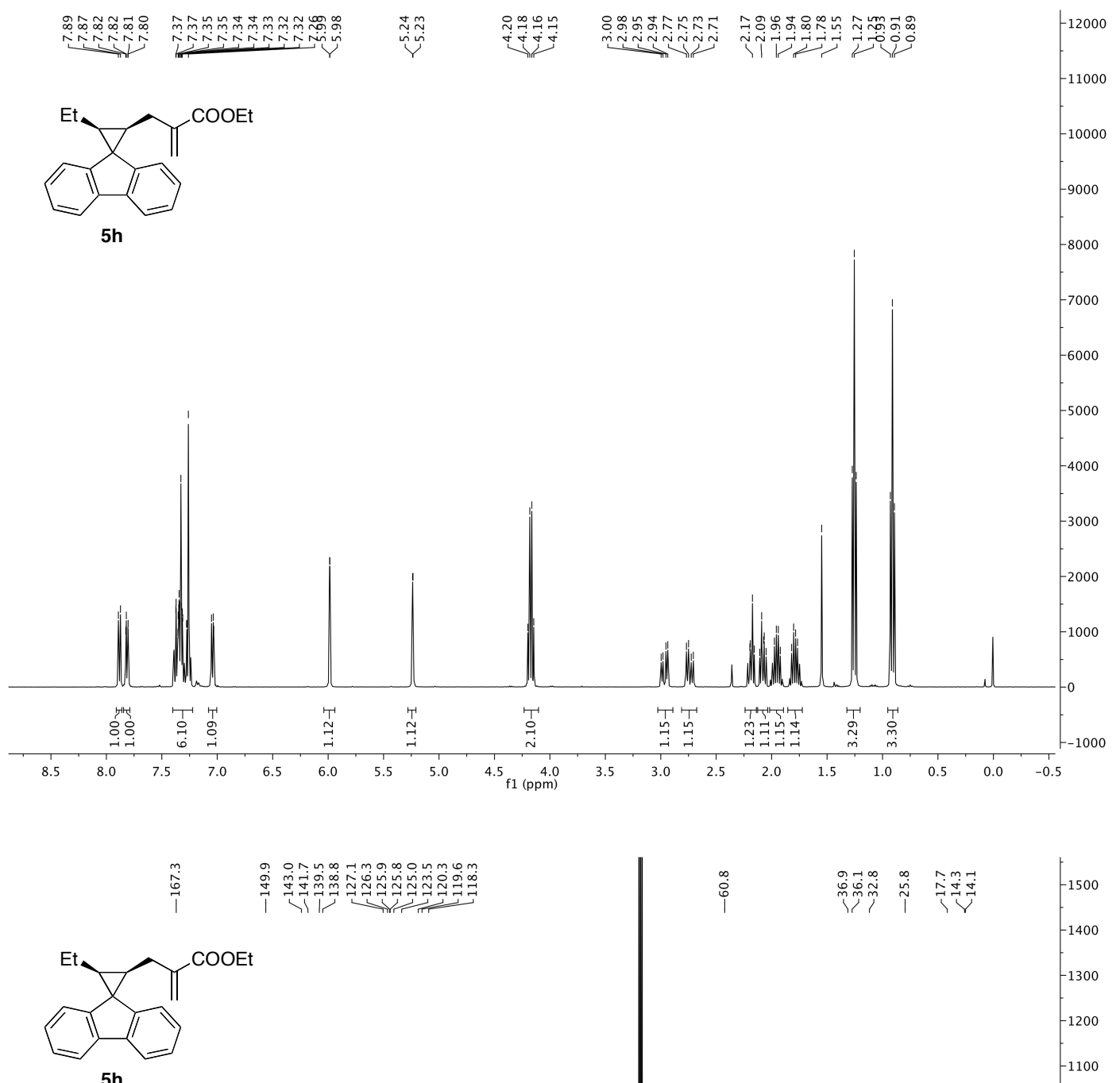

$5 \mathrm{~h}$

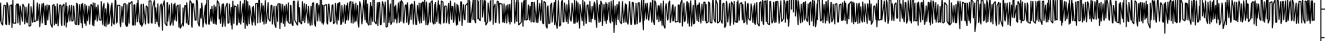




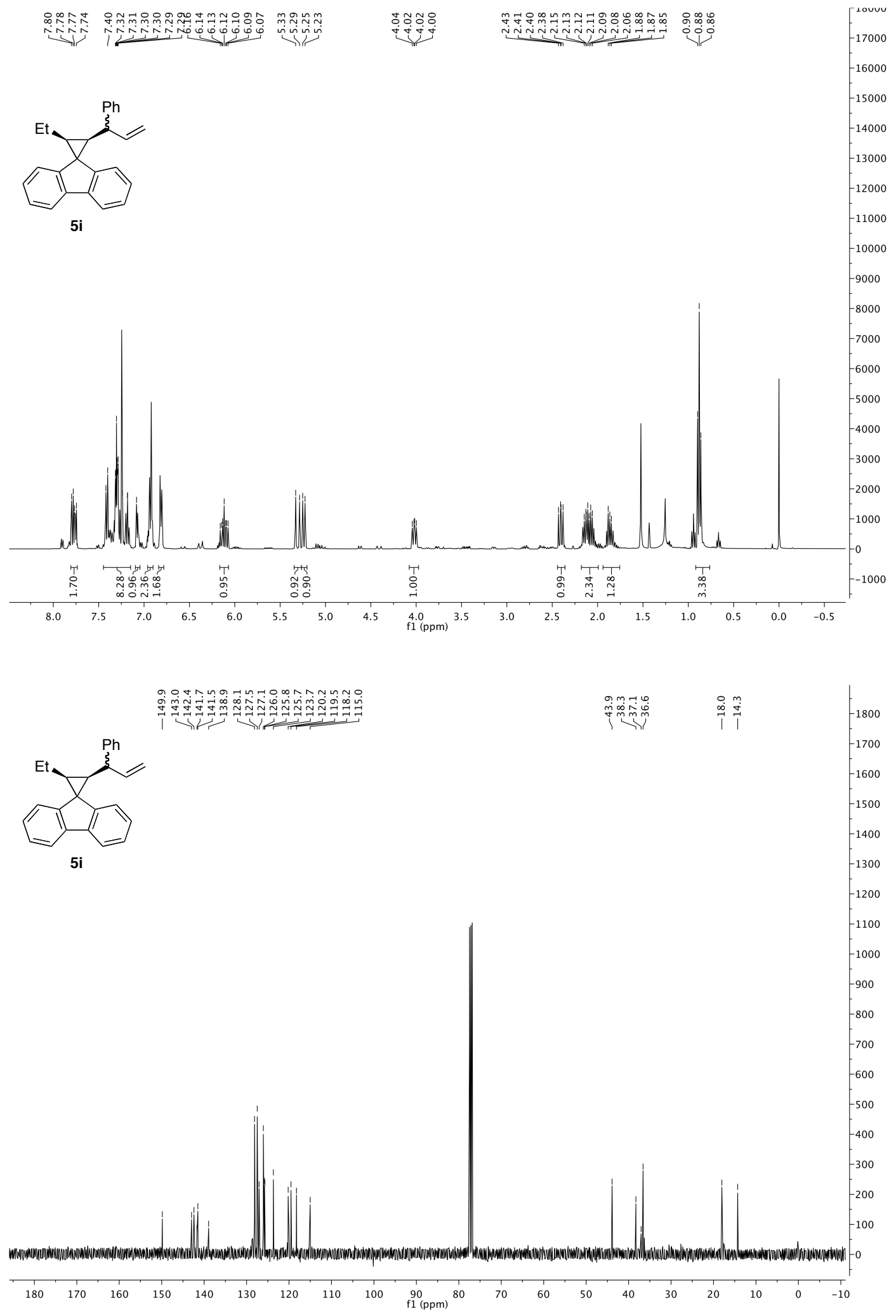



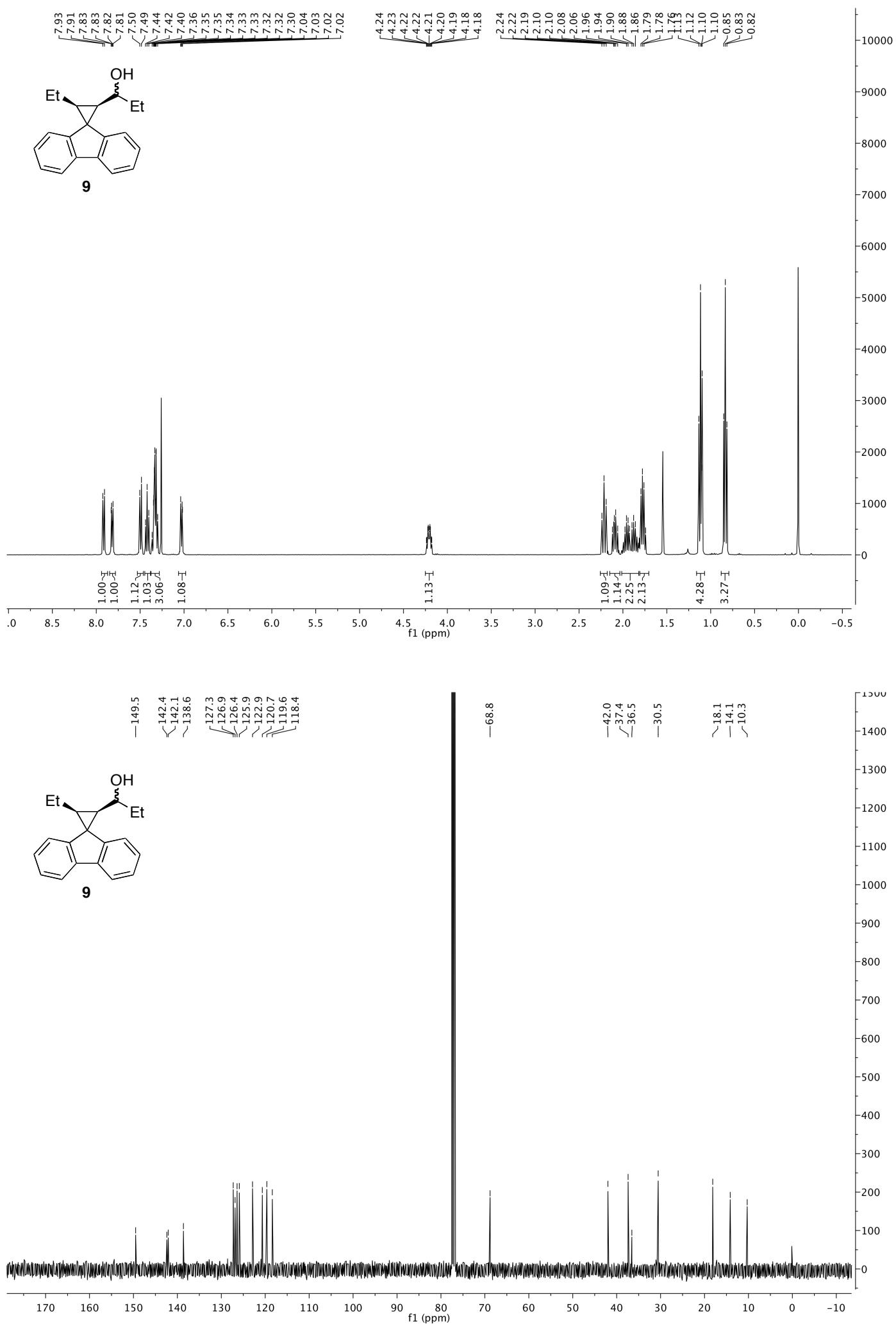

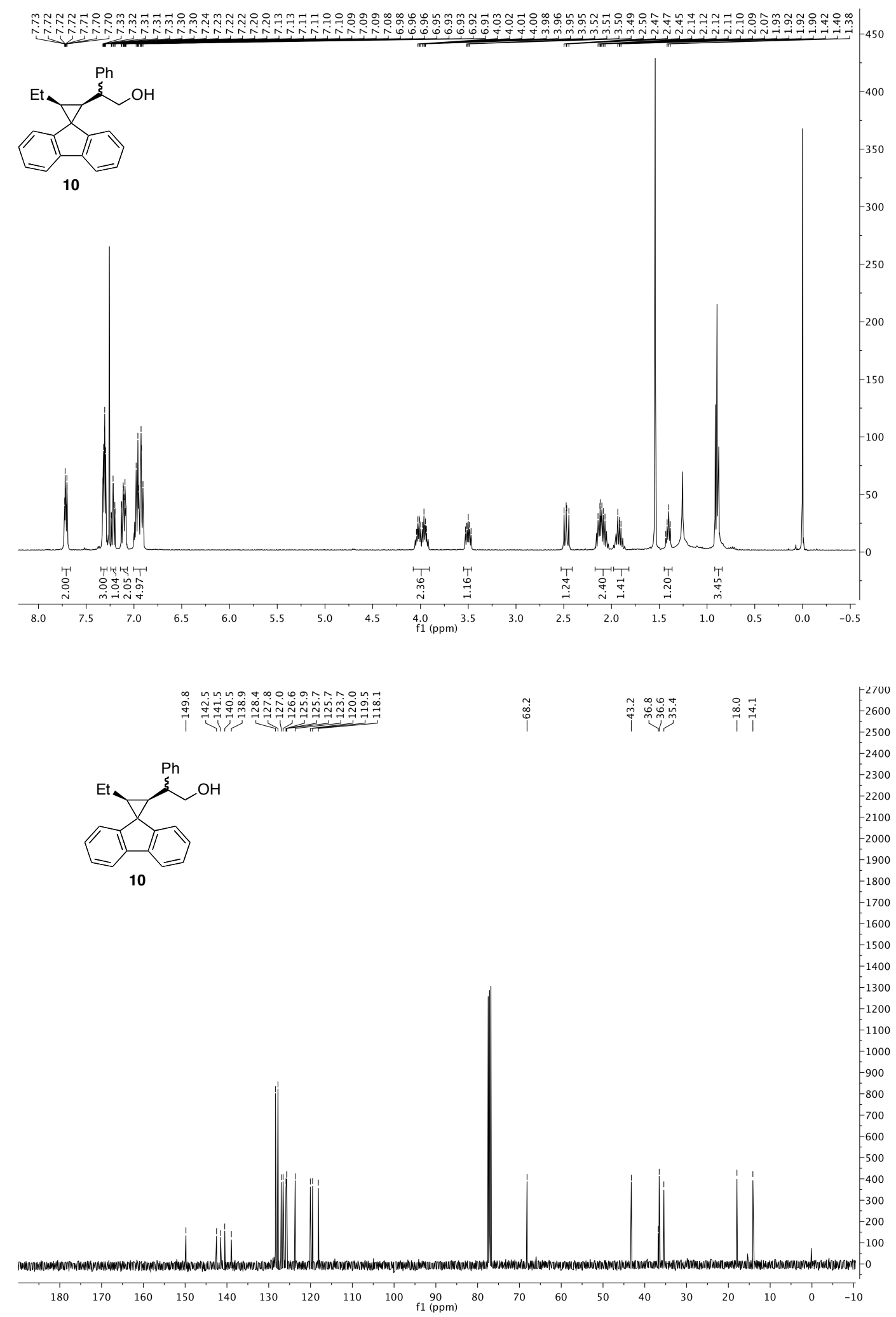